\title{
PERSEPSI SISWA TENTANG KEADAAN PSIKOLOGIS SENSE OF HUMOR GURU DENGAN MOTIVASI BELAJAR SISWA KELAS VII SMPN 3 BATUSANGKAR
}

\author{
Dwi Wahyuni \\ Universitas Negeri Padang \\ Jln. Prof. Dr. Hamka, Air Tawar Barat Kecamatan Padang Utara, Kota Padang \\ dwahyuni@yahoo.co.id
}

\begin{abstract}
This study is the students' perceptions about the teachers' psychological sense of humor toward the learning motivation of grade VII SMPN 3 Batusangkar showed a positive relationship. There is a relationship between students' perceptions about the sense of humor with the learning motivation. This research is a correlation research that shows a positive relationship. The population of this study was the students of grade VII SMPN 3 Batusangkar which amounted to 214 people with the sample of the study amounted to 54 people taken with random sampling. The instrument in this research is questionnaire which Likert scale with four choices of answers consisting of: SS (Strongly agree, S (Agree), TS (Disagree), and STS (strongly disagree) The results of this study illustrates that there is a positive relationship of humor with the students motivation to learn who give a good impact in learning process with a pleasant situation and comfortable and not rigid so it can improve the spirit of student learning.
\end{abstract}

Keywords: Student Perceptions, Sense Of Humor, and Student Learning Motivation

\section{PENDAHULUAN}

Quasana belajar yang menyenangNan membuat siswa memusatkan perhatiannya secara penuh pada saat belajar. Dalam usaha ini banyak cara yang dilakukan untuk menciptakan konsidi-kondisi tertentu. Seorang guru bertanggung jawab untuk mengkomunikasikan dan menentukan jenis lingkungan psikososial dalam kelas. Sesnse Of Humor adalah keadaan psikologis yang dilakukan oleh guru untuk menciptakan suasana menyenagkan di dalam kelas (Slameto,2003). Penting bagi guru untuk menggunakan sense of humor dalam kelas untuk meningkatkan motivasi belajar siswa. Hal ini sesuai dengan pernyataan seorang guru yang diwawancarai pada tanggal 12 Juni 2010 yang menyatakan bahwa hunor diperlukan dalam proses belajar mengajar untuk mengurangi rasa jenuh siswa terhadap materi pelajaran yang diberikan serta hal itu bisa menjadi dorongan untuk siswa dalam memahami pelajaran karena terkesan ringan dan penuh canda.

Selain pernyataan guru tersebut hal ini diperkuat oleh pernyataan siswanya yang menyatakan bahwa mereka sangat senang kalau gurunya suka menggunakan humor pada saat mengajar karena hal itu membuat mereka lebih mengerti dengan pelajaran bahkan tidak bosan, tetapi 
ada juga siswa yang menyatakan humor yang disajikan gurunya ketika pelajaran terkadang kaku dan tidak mengenakan bahkan ada yang melecehkan orang lain.

Sense of humor mengurangi kebosanan dan membantu siswa dalam memusatkan perhatian mereka sehingga mereka bisa belajar. Menurut Berk (dalam Lovorn, 2008), menyatakan sense of humor membuka komunikasi yang tidak didasarkan pada ketakutan atau intimidasi sebaliknya komunikasi positif, konstruktif, santai, yang secara kontinyu terjadi di seluruh kelas. Penempatan sense of humor yang baik akan dapat menimbulkan perasaan senang terhadap pelajaran sehingga dapat menimbulkan motivasi karena rasa senang merupakan dorongan yang berasal dari dalam diri individu yang menjadi pergerakan untuk melakukan sesuatu. Motivasi dapat diartikan sebagai kekuatan (energi) penggerak seseorang yang dapat menimbulkan tingkat persistensi dan antusiasmenya dalam melaksanakan suatu kegiatan, baik yang bersumber dari dalam diri individu sendiri (motivasi intrinsik) maupun dari luar individu (motivasi ekstrinsik) (Wijaya, 2009).

Seorang guru perlu menumbuhkan motivasi belajar siswa. Untuk memperoleh hasil belajar yang optimal, guru dituntut kreatif membangkitkan motivasi belajar siswa, sehingga terbentuk perilaku belajar siswa yang efektif. Semangat belajar muncul ketika suasana begitu menyenangkan dan belajar akan efektif bila siswa dalam keadaan gembira. Upaya untuk menciptakan suasana menyenangkan dalam pembelajaran dapat dilakukan dengan berbagai metode dan menerapkan dalam pembelajaran dapat dilakukan dengan berbagai metode dan menerapkan berbagai strategi untuk meningkatkan motivasi belajar.

Komunikasi dan interaksi guru dengan peserta didik yang terbuka dan penuh keriangan dapat menciptakan suasana menyenangkan dalam belajar. Lingkungan fisik belajar yang kondusif memungkinkan siswa dapat bereaksi dengan penuh motivasi (nabar,2009). Memberikan kegembiraan kepada siswa dengan sisipan humor akan dapat membantu siswa secara emosional. Siswa akan dapat mengatasi berbagai hambatan emosional yang sering mengganggu kelancara belajar seperti kejenuhan, stress dan lain-lain (Nabar,2009).

Suasana menyenangkan dalam pembelajaran juga sekaligus dapat menstimulus emosi dan memori yang dapat memberikan kemampuan kepada siswa untuk mengingat dalam waktu lama dan dapat dipanggil kembali saat informasi diperlukan dalam ujian. Dengan demikian sisipan humor ini akan dapat menciptakan suasana menyenangkan dalam belajar dan pada gilirannya akan meningkatkan motivasi siswa. Diterapkannya sense of humor dalam proses belajar maka diharapkan dapat membangkit- 
kan motivasi belajar siswa karena sense of humor menjauhkan siswa dari situasi jenuh, menghentikan lamunan karena suasana yang membosankan, menimbulkan suasana menyengkan, serta memudahkan siswa untuk mengingat informasi yang didengar karena terdapat perasaan senang pada saat mendengat hal tersebut namun hal ini tidak lepas dari persepsi siswa itu sendiri terhadap sense of humor.

Berdasarkan gambaran diatas peneliti ingin mengetahui hubungan persepsi siswa tentang keadaan psikologis sense of humor guru dengan motivasi belajar siswa kelas VII SMPN 3 Batusangkar.

\section{TEORI}

\section{Pengertian Motivasi Belajar}

Motivasi disebut sebagai daya penggerak perilaku sekaligus menjadi penentu perilaku. Motivasi juga dapat dikatakan sebagai suatu konstruk teoritis mengenai terjadinya perilaku meliputi pengaturan (regulasi), pengarahan (directive), dan tujuan dan perilaku (shaleh, 2008:182). Sementara itu dalam Santrock (2008:510) motivasi adalah proses yang memberi semangat, arah, dan kegigihan perilaku yang penuh energi artinya perilaku yang termotivasi adalah perilaku yang penuh energi, terarah, dan bertahan lama.

Manusia merupakan makhluk tuhan yang mempunyai daya gerak dari dalam dirinya dan hal ini disebut dengan motivasi (Adi, 1994:154). Demikian pula dalam belajar, belajar merupakan suatu proses usaha yang dilakukan seseorang untuk memperoleh perubahan tingkah laku yang baru secara keseluruhan, sebagai hasil pengamalannya sendiri dalam interaksi lingkungan (Slameto,2003). Namun pada intinya bahwa motivasi merupkan kondisi psikologis yang mendorong seseorang untuk melakukan sesuatu. Dalam kegiatan belajar, motivasi dapat dikatakan sebagai keseluruhan daya penggerak di dalam diri sisiwa yang menimbulkan, menjamin kelangsungan dan memberikan arah kegiatan belajar, sehingga diharapkan tujuan dapat tercapai. Dalam kegiatan belajar, motivasi sangat diperlukan, sebab seseorang yang tidak mempunyai motivasi dalam belajar tidak akan mungkin melakukan aktivitas belajar.

Dalam kegiatan belajar mengajar, apabila ada seseorang siswa misalnya tidak berbuat sesuatu yang seharusnya dikerjakan maka perlu diselidiki sebabnya. Sebab itu biasanya bermacam-macam dan hal ini berarti pada diri anak tidak terjadi perubahan energi, tidak terangsang afeksinya untuk melakukan sesuatu karena tidak memiliki tujuan atau kebutuhan belajar (Sardiman, 2003:74). Terjadinya perbedaan reaksi atau aktifitas dalam belajar dapat dikarenakan oleh adanya perbedaan motivasi. Motivasi dalam belajar tidak saja merupakan sesuatu 
energi yang menggerakkan siswa untuk belajar tetapi juga sesuatu yang mengarahkan siswa kepada tujuan belajar, dengan kata laian betapapun baiknya potensi anak yang eliputi kemampuan intelektual atau bakat siswa, materi yang diajarkan, dan lengkapnya sarana belajar. Namun jika siswa tidak termotivasi dalam belajar maka proses belajar tidak berlangsung dengan optimal dan sebaliknya hasil belajar akan optimal kalau ada motivasi yang tepat (Prayitno, 1989:8).

Berdasarkan penjelasan diatas dapat disimpulkan bahwa motivasi belajar dapat dikatakan sebagai keseluruhan daya penggerak didalam diri siswa yang menimbulkan kegiatan belajar, yang menjamin kelangsungan dari kegiatan belajar dan yang memberikan arah pada kegiatan belajar, sehingga tujuan yang dikehendaki oleh subjek belajar itu dapat tercapai.

\section{Persepsi Siswa}

Menurut Rita L. Atkinson (2005:201) persepsi adalah proses dimana kita mengorganisasi dan menafsirkan pola stimulus dalam lingkungan. Ditambahkan dengan pendapat Davidoff (1994:46) persepsi yaitu suatu stimulus yang diindera oleh individu lalu organisasikan, kemudian diinterprestasikan, sehingga individu menyadari, mengerti apa yang diindera itu. Sementara itu menurut Slameto (2003:102) persepsi adalah suatu proses yang menyangkut masuknya pesan atau informasi ke dalam otak manusia. Melalui persepsi manusia terus-menerus mengadakan hubungan dengan lingkungannya. Dan dalam Abdul (2008:110) persepsi adalah kemampuan membedabedakan, mengelompokkan, memfokuskan perhatian terhadap suatu objek rangsangan. Dalam proses pengelompokkan dan membedakan ini persepsi melibatkan proses interpretasi berdasarkan pengalaman terhadap suatu peristiwa atau objek.

Berdasarkan uraian diatas persepsi merupakan suatu proses kemampuan membedakan, mengelompkkan, memfokuskan perhatian kemudian menginterpretasikan suatu hal sehingga individu dapat menyadari hal tersebut. Faktor yang mempengaruhi persepsi menurut Robbins dalam Muchlas Machmuri (1994:69) adalah :

b. Perilaku persepsi dalam meberikan interpretasi terhadap objek yang dilihat dipengaruhi oleh karakteristik pribadi antara lain sikap, motif, interest dan pengalaman masa lalu.

c. Target persepsi, karakteristik dalam target persepsi yang sedang diobservasi dalam mempengaruhi apa saja yang dipersepsikan seperti gerak, suara, ukuran dan berbagai atribut lainnya

d. Konteks situasi dimana persepsi dibuat, elemen dalam lingkungan sekitarnya dapat mempengaruhi persepsi 


\section{Sense Of Humor}

Dalam psikologi kontemporer, pengertian istilah "humor" mengacu pada humor sebagai sifat kepribadian yang abadi. Ada sedikit kesepakatan tentang cara menetapkan dan mengukur rasa humor sebagai suatu sifat, dan peneliti menggunakan istilah tersebut dalam berbagai cara. Jadi bagaimanapun sense of humor dapat dikonseptualisasikan sebagai suatu pola perilaku kebiasaan (kecendrungan untuk sering tertawa, untuk menceritakan lelucon dan menghibur orang lain, untuk menertaakan lelucon orang lain), kemampuan (kemampuan membuat humor untuk menghibur orang lain, untuk lucu untuk mengingat lelucon), suatu sifat temperamental (keceriaan, kebiasaan), respon estetik )kesenanngan tertentu akan jenis lelucon), sikap (sikap positif terhadap humor dan orang-orang lucu), pandangan dunia atau strategi menghadapi (kecendrungan untuk mempertahankan perspektif humor, menghadapi kesulitasn (Martin,2010).

Sense of humor menurut Martin (dalam Hughes, 2008) diartikan sebagai perbedaan sifat individu seperti dalam persepsi, ekspresi, atau menikmati humor. Sebagai variabel perbedaan individu, dengan potensi untuk pengembangan, Lefcourt menjelaskan, sense of humor dikaitkan dengan berbagai hasil positif yang tidak terbatas untuk mengatasi, daya tarik sosial dan konsep diri yang positif. Dalam penelitian Uno (2007) secara sederhana sense of humor didefenisikan sebagai sesuatu yang lucu, humor merefleksikan kegembiraan manusia dalam menertawakan dirinya sendiri dan masyarakat. Pada umumnya sense of humor mempunyai makna yang disepakati bersama secara kolektif sebagai sesuatu yang bersifat atau bernuansa jenaka dan bertabus gelak tawa.

Pemahaman terhadap definisi sense of humor sangat diperlukan karena hampir selalu terjadi kesenjangan antara makna teoritis dan pemahaman praktis yang berdampak pada interpretasi dan penerapan dalam berbagai situasi hubungan interpersonal. Kesenjangan yang paling sering terjadi itu adalah tumpang tindih pemahaman antara sense of humor dan joke. Berdasarkan tinjauan beberapa defenisi tentang sense of humor, Utomo menyimpulkan bahwa sense of humor adalah kemampuan individu untuk mengubah persepsi kognitif secara cepat dan mengekspresikannya secara terbuka tanpa berakibat tidak menyenangkan bagi orang lain, dengan cara memandang masalah dari perspektif yang berbeda (yaitu dari segi kelucuannya) untuk mengurangi perasaan cemas dan tidak berdaya.

Jadi berdasarkan defenisi diatas sense of humor merupakan kemampuan individu untuk menimbulkan suatu ransangan yang mengubah persepsi kognitif secara cepat dan mengekspresikannya secara 
terbuka tanpa berakibat tidak menyenangkan bagi orang lain, dengan cara memandang masalah dari perspektif yang berbeda (yaitu dari segi kelucuannya) untuk mengurangi perasaan cemas dan tidak berdaya dan mengarahkannya pada perasaan senang dan nyaman.

Aspek sense of humor menurut Thorson dan Powel (1997) adalah sebagai berikut:

\section{1) Humor Production}

$\begin{array}{lr}\text { Kemampuan } & \text { untuk } \\ \text { menemukan humor pada }\end{array}$ setiap peristiwa dan berhubungan dengan perasaan diterima disetiap lingkungan

2) Copying with humor Bagaimana individu menggunakan humor untuk mengatasi emmosional dan situasi yang mengandung stressful pada individu

3) Humor appreciation Kemampuan untuk mengapresiasikan humor yang berhubungan dengan internal locus of control seseorang sebuah indikasi dari beberapa banyak individu mengapresiasikan setiap peristiwa lucu sebagai bagian dari perilaku orang lain

4) Attitude toward humor

Kecendrungan untuk tersenyum atau tertawa pada setiap situasi yang lucu

Fungsi sense of humor menurut Nilsen dalam Hawkins (2008) meliputi: a) Fisiologis

Humor dan bermain dapat mengalihkan susunan kimia internal seseorang dan mempunyai akibat yang sangat besar pada sistem seseorang termasuk sistem saraf, peredaran darah enndokrin dan sistem kekebalan. Fungsi fisiologis termasuk kegembiraan, relaksasi dan penyembuhan

b) Psikologis

Humor efektif menolong seseorang dalam kesukaran. Kemampuan melihat humor dalam suatu situasi merupakan salah satu yang dapat digunakan untuk mengatasi krisis dalam hidup sebagai perlindungan terhadap perubahan dan ketidaktentuan. Fungsi psikologis berisi lega, pertahanan ego, mengatasi dan memperoleh status.

c) Pendidikan

Humor dan tertawa menyebabkan seseorang lebih waspada, otak digunakan dan mata bersinar. Oleh karena itu humor dan tertawa merupakan alat belajar yang penting. Selain itu humor merupakan alat yang sangat efektif untuk membawa seseorang agar dapat mendengarkan pembicaraan dan merupakan lat persuasu yang baik. Fungsi pendidikan terdiri dari kewaspadaan, berdebat dan 
membujuk, mengajar secara efektif dan memori jangka panjang belajar.

d) Sosial

Humor tidak hanya dapat digunakan untuk mengikat seseorang atau kelompok yang disukai. Fungsi sosial meliputi ikatan dengan orang-orang yang seperti kita, mempromosikan stabilitas sosial dan mempromosikan perubahan sosial.

\section{Hubungan persepsi siswa tentang Sense of humor guru dengan motivasi belajar}

Proses belajar mengajar akan senantiasa merupakan proses kegiatan interaksi antara dua unsur manusiawi yakni siswa sebagai pihak yang belajar dan guru sebagai pihak yang mengajar dengan siswa sebagai objek pokok yang ingin meraih cita-cita, memiliki tujuan dan kemudian ingin mencapainya secara optimal. Hasil belajar akan menjadi optimal jika ada motivasi. Perwujudan interaksi guru dan siswa harus lebih banyak berbentuk pemberian motivasi dari guru kepada siswa agar siswa merasa bergairah memiliki semangat, potensi dan kemampuan yang dapat meningkatkan harga diri. Dengan adanya motivasi siswa diharapkan lebih efektif dalam melakukan kegiatan belajar (Sadirman, 2003).

Santrock (2008) menyatakan bahwa siswa yang merasa didukung dan diperhatikan oleh guru lebih termotivasi untuk melakukan kegiatan akademik daripada siswa yang tidak didukung dan diperhatikan gurunya. Menurut pendapat Gurtler bagi para guru, keberhasilan diduga dapat ditemukan dalam pendekatan yang membuat koneksi yang relevan dan mendorong berpikir tinggi. Menariknya, salah satu unsur pembangunan manusia yang telah terbukti memperbaiki akhlak hubungan kekeluargaan dan mendorong keunggulan akademik seringkali diabaikan oleh orang tua dan guru dalam upaya ini elemen itu adalah humor.

Hal ini diperkuat dengan penjelasan Lundberg \& Thurston bahwa manfaat menggunakan humor sebagai dasar belajar bagi anak yang berhubungan dengan perkembangan mereka sebelum memasuki masa remaja. Sementara itu menurut Freud, humor dalam hal ini dianggap dapat memfasilitasi pembelajaran.

Dalam studi pada siswa keperawatan didapati bahwa humor yang diberikan dalam kelas memberikan manfaat yang dapat dirasakan oleh siswa seperti, humor untuk menghilangkan stress, humor untuk memusatkan perhatian, humor untuk membuat belajar menyenangkan, humor untuk membantu pembelajaran, humor untuk memperkuat hubungan sosial. Dimana manfaat yang dirasakan tersebut membuat siswa termotivasi untuk belajar karena situasi yang didapatkan itu membuat pengalaman dan kondisi yang positif (Ahem R. Tracy,2008). 
Sebuah penelitian tentang penggunaan humor dalam kelas matematikan menyatakan bahwa humor memperkuat hubungan antara siswa dan guru, mengurangi strs, membuat proses belajar lebih menarik dan jika humor yang disajikan berkaitan dengan topik pelajaran maka akan dapat meningkatkan ingatan tentang pelajaran tersebut. Cerita humor dalam pelajaran matematika dapat membuat siswa lebih perhatian terhadap pelajaran tersebut selain itu humor juga dapat menjelaskan suatu makna pelajaran dalam cara yang tidak mengancam sehingga memotivasi siswa yang sebelumnya takut untuk bekerja menjadi lebih percaya diri dalam bekerja. (Warwick,2009).

Humor dapat meningkatkan dan mempertahankan minat belajar siswa dan menyediakan sarana untuk terlibat dalam pemikiran yang berbeda. Menurut Rossett menunjukkan bahwa bukan hanya humor memungkinkan belajar, tetapi menunjukkan suatu korelasi antara pengembangan rasa humor dan motivasi untukbelajar, penguasaan bahan dan positif respon terhadap ransangan pembelajaran (Maier,2008).

Ada beberapa alasan humor digunakan dalam kelas menurut Feigelson yaitu sebagai cara untuk menempatkan siswa merasa nyaman, sebagau pengambil perhatian, sebagai cara untuk menunjukkan guru adalah manusia sebagai elemen penting dari lingkungan kolaboratif. Hal ini juga diperkuat dengan pernyataan Dolt dalam sebuah penelitian. Penelitian menunjukkan humor bisa membuat pengalaman belajar lebih menyengkan karena siswa lebih mudah teringat dengan kata-kata lucu.

Namun harus disesuaikan dengan pengetahuan. Hal ini juga menunjukkan bahwa humor dapat secara efektif digunakan untuk meningkatkan perhatian siswa, meningkatkan lingkungan kelas dan kegelisahan tes lebih rendah. Melalui penelitian Dr. Berk menyatakan bahwa tertawa membantu siswa belajar lebih banyak. Ia menyatakan bahwa untuk menjadi efektif, komedi harus memuji, tidak mengalihkan perhatian dari materi pelajaran. Para peneliti percaya bahwa humor berfungsi untuk membangkitkan minat dan perhatian siswa. Peningkatan pada gilirannya memotivasi siswa dan meningkatkan kemungkinan mereka memahami dan menyimpan informasi.

\section{METODOLOGI}

Penelitian ini termasuk jenis penelitian korelasional yaitu penelitian yang bertujuan untuk menyelidiki sejauhmana variasivariasi pada faktor berkaitan dengan variasi pada faktor lain berdasarkan pada koefisien korelasi. A. Muri Yusuf (1997) bahwa penelitian korelasional adalah suatu tipe penelitian yang melihat hubungan antara satu atau beberapa ubahan 
dengan satu atau beberapa ubahan yang lain.

Penelitian ini dilakukan untuk melihat sejauhmana suatu variabel berhubungan dengan variabel lain. Dalam penelitian ini yang dijadikan variabel $\mathrm{X}$ adalah Sense of humor guru sedangkan variabel $\mathrm{Y}$ adalah motivasi belajar siswa.

Populasi dalam penelitian ini adalah siswa kelas VII SMPN 3 Batusangkar yang berjumlah 214 orang. Sampel dilakukan dengan teknik random sebanyak $25 \%$ dengan jumlah 54 orang. Hal ini sesuai dengan pendapat Arikunto (1997) bahwa apabila subjek penelitian kurang dari 100 orang, maka lebih baik diambil semuanya sehingga penelitian merupakan penelitian populasi. Selanjutnya jika jumlah subjeknya besar, maka diambil diantara 10\%-15\% atau 20\%-25\% atau lebih. Penelitian ini menggunakan instrumen angket dengan skala likert dengan empat alternatif jawaban yaitu SS(sangat setuju), S( Setuju), TS (Tidak Setuju), dan STS (Sangat tidak setuju). Pengolahan data dilakukan dengan bantuan SPSS versi12.0.

\section{HASIL PENELITIAN}

\section{Persepsi Sense of Humor}

Respon skala persepsi tentang Keadaan psikologis Sense of humor terdiri dari SS, S,TS dan STS dengan skor berkisar antara 1-4. Rentang maksimum skor skala yaitu $35 \times 4=140$ dan rentang minimimnya $35 \times 1=35$, sehingga luas sebenarnya yaitu 140$35=105$. Dengan demikian standar deviasi yaitu $105 / 6=17,5$, dan mean hipoteknya $35 \times 2,5=87,5$. Kategori skor persepsi tentang sense of humor dapat dilihat pada tabel berikut:

Tabel Kategori Skor Sense Of Humor

\begin{tabular}{|c|c|c|c|c|}
\hline $\begin{array}{l}\text { Standar } \\
\text { Deviasi }\end{array}$ & Skor & $\begin{array}{l}\text { Katego } \\
\text { ri }\end{array}$ & $\mathrm{F}$ & $\%$ \\
\hline $\begin{array}{l}X<(\mu- \\
0,5 \sigma)\end{array}$ & $\begin{array}{l}0 \leq X<6 \\
1,25\end{array}$ & $\begin{array}{l}\text { Sangat } \\
\text { Rendah }\end{array}$ & 0 & $0 \%$ \\
\hline $\begin{array}{l}(\mu- \\
1,5 \sigma)< \\
X \leq(\mu- \\
0,5 \sigma)\end{array}$ & $\begin{array}{l}61,25< \\
X \leq 78 \\
75\end{array}$ & Rendah & 0 & $0 \%$ \\
\hline $\begin{array}{l}(\mu- \\
0,5 \sigma)< \\
X \leq(\mu+0 \\
, 5 \sigma)\end{array}$ & $\begin{array}{l}78,75< \\
X \leq 96 \\
25\end{array}$ & Rendah & 17 & $\begin{array}{l}31,48 \\
\%\end{array}$ \\
\hline $\begin{array}{l}(\mu+0,5 \sigma \\
)<X \leq(\mu \\
+0,5 \sigma)\end{array}$ & $\begin{array}{l}96,25< \\
X \leq 113 \\
, 75\end{array}$ & Tinggi & 29 & $\begin{array}{l}53,70 \\
\%\end{array}$ \\
\hline $\begin{array}{l}(\mu+0,5 \sigma \\
)<X\end{array}$ & $\begin{array}{l}113,75 \\
\leq X\end{array}$ & $\begin{array}{l}\text { Sangat } \\
\text { Tinggi }\end{array}$ & 8 & $\begin{array}{l}14,82 \\
\%\end{array}$ \\
\hline \multicolumn{3}{|l|}{ Jumlah } & 54 & $100 \%$ \\
\hline
\end{tabular}

Dari kategori skala persepsi tentang sense of humor dapat dilihat bahwa subjek secara umum memiliki tingkat persepsi terhadap sense of humor sedang sebanyak 17 orang $(31,48 \%)$ dan memiliki sense of humor tinggi sebanyak 29 orang $(53,70)$ serta memiliki persepsi tentag sense of humor sangat tinggi sebanyak $8(14,28 \%)$.

Berdasarkan pengkategorian skor persepsi tentang sense of humor diketahui bahwa persepsi siswa SMPN 3 Batusangkar sebanyak $31,48 \%$. Hal ini berarti bahwa siswa mempersepsikan sense of humor guru senang, yakni tidak mempersepsikan 
baik maupun tidak baik artinya siswa tidak selalu mempersepsikan sense of humor sebagai suatu yang menyenangkan tapi tidak mempersepsikan sense of humor guru sebagai sesuatu yang mengganggu pelajaran.

Selanjutnya persepsi senses of humor yang tergolong tinggi yakni sebanyak $53,70 \%$ sebagai suatu yang menyenangkan dalam proses pembelajaran atau baik dilakukan. Sedangkan pada tingkat selanjutnya sebanyak $\quad 14,82 \% \quad$ siswa mempresepsikan sense of humor sebagai sesuatu yang sangat menyenangkan dalam proses pelajaran atau sangat baik dilakukan dalam proses pembelajaran.

Berdasarkan hasil analisis menyatakan terdapat hubugnan yang positif antara persepsi siswa tentang sense of humor guru dengan motivasi belajar siswa kelas VII SMPN 3 Batusangkar dengan koefisien korelasi 0,586, $\mathrm{p}=0,000 \quad(\mathrm{p}<0,001)$. Dengan demikian dapat disimpulkan bahwa hubungan antara persepsi siswa tentang sense of humor guru dengan motivasi belajar siswa kelas VII SMPN 3 Batusangkar pada rentang sama-sama tinggi.

Utomo (2007) mengatakan sense of humor merupakan kemampuan individu untuk menimbulkan suatu ransangan yang mengubah persepsi kognitif secara cepat dan mengekpresikannya secara terbuka tanpa berakibat tidak menyenangkan bagi orang lain dengan cara memandang masalah dari perspektif yang berbeda untuk mengurangi perasaan cemas dan tidak berdaya dan mengarahkannya pada perasaan senang dan nyaman.

\section{Motivasi Belajar}

Respon skala motivasi belajar terdiri dari SS, S, TS dan STS dengan skor berkisar antara 1-4. Rentang maksimum skor skala yaitu $42 \times 4=168$ dan rentang minimumnya $42 \times 1=42$, sehingga luas sebenarnya yaitu 168$42=126$. Dengan demikian standar deviasi yaitu $126 / 6=21$ dan mean hipotetiknya $42 \times 2,5=105$. Kategori skor motivasi belajar dapat dilihat pada tabel berikut:

Tabel Kategori Skor Motivasi Belajar

\begin{tabular}{|c|c|c|c|c|}
\hline $\begin{array}{l}\text { Standar } \\
\text { Deviasi }\end{array}$ & Skor & $\begin{array}{l}\text { Katego } \\
\text { ri }\end{array}$ & $\mathrm{F}$ & $\%$ \\
\hline $\begin{array}{l}X<(\mu- \\
0,5 \sigma)\end{array}$ & $\begin{array}{l}0 \leq X<7 \\
3,5\end{array}$ & $\begin{array}{l}\text { Sangat } \\
\text { Rendah }\end{array}$ & 0 & $0 \%$ \\
\hline $\begin{array}{l}(\mu- \\
1,5 \sigma)< \\
X \leq(\mu- \\
0,5 \sigma)\end{array}$ & $\begin{array}{l}73,5< \\
X \leq 94 \\
5\end{array}$ & Rendah & 0 & $0 \%$ \\
\hline $\begin{array}{l}(\mu- \\
0,5 \sigma)< \\
X \leq(\mu+0 \\
, 5 \sigma)\end{array}$ & $\begin{array}{l}94,5< \\
X \leq 115 \\
, 5\end{array}$ & Rendah & 7 & $\begin{array}{l}12,96 \\
\%\end{array}$ \\
\hline $\begin{array}{l}(\mu+0,5 \sigma \\
)<X \leq(\mu \\
+0,5 \sigma)\end{array}$ & $\begin{array}{l}115,5< \\
X \leq 136 \\
, 5\end{array}$ & Tinggi & 27 & $\begin{array}{l}50,00 \\
\%\end{array}$ \\
\hline $\begin{array}{l}(\mu+0,5 \sigma \\
)<X\end{array}$ & $\begin{array}{l}136,5 \leq \\
X\end{array}$ & $\begin{array}{l}\text { Sangat } \\
\text { Tinggi }\end{array}$ & 20 & $\begin{array}{l}37,04 \\
\%\end{array}$ \\
\hline \multicolumn{3}{|l|}{ Jumlah } & 54 & $100 \%$ \\
\hline
\end{tabular}

Dari kategori skala motivasi belajar dapat dilihat bahwa subjek secara umum memiliki tingkat motivasi belajar yang sedang sebanyak 7 orang (12,96\%), memiliki 
tingkat motivasi belajar yang tinggi sebanyak 27 orang $(50,00 \%)$ serta memiliki tingkat motivasi belajar sangat tinggi 20 orang $(37,04 \%)$.

Motivasi belajar adalah keseluruhan daya penggerak didalam diri siswa yang menimbulkan kegiatan belajar yang menjamin kelangsungan dari kegiatan belajar dan memberikan arah pada kegiatan belajar sehingga tujuan yang dikehendaki oleh subjek belajar itu dapat tercapai. Menurut Nabar (2009) seorang guru perlu menumbuhkan motivasi belajar siswa. Untuk memperoleh hasil belajar yang optimal, guru dituntut kreatif membangkitkan motivasi belajar siswa sehingga terbentuk perilaku belajar siswa yang efektif. Semangat belajar muncul ketika suasana begitu menyenangkan dan belajar akan efektif bila siswa dalam keadaan gembira.

Hasil penelitian ini juga sesuai dengan hasil wawancara dan observasi yang dilakukan peneliti kepada siswa dan guru dari SMPN 3 Batusangkar, mereka menyatakan bahwa siswa lebih menginginkan guru yang belajar penuh dengan canda dan tidak selalu tegang, kaku, serius didepan kelas. Begitu juga dengan guru yang menyatakan suasana belajar yang kaku membuat siswa malas belajar dan sering terkantuk dan melamun. Namun seiring dengan adanya humor dapat membuat siswa lebih bersemangat dan merasakan fresh dalam belajar.

Jadi dapat disimpulkan bahwa ada hubungan antara persepsi siswa tentang kegiatan psikologis sense of humor guru dengan motivasi belajar yang menyenangkan dan membuat proses belajar lebih menarik yang akan mengurangi ketegangan dan kecemasan siswa, meningkatkan ingatan tentang pelajaran, humor dapat menjelaskan suatu makna pelajaran dalam cara yang tidak mengancam, emningkatkan dan mempertahankan minat belajar sehingga memotivasi siswa.

\section{PENUTUP}

Berdasarkan pengolahan data dapat disimpulkan:

1. Tingkat persepsi siswa tentang kegiatan psikologi sense of humor guru subjek penelitian secara umum berada pada kategori sedang yakni sebanyak 53,70\% yang berarti bahwa siswa mempresepsikan sense of humor sebagai suatu yang menyenangkan dalam proses pelajaran atau baik dilakukan.

2. Tingkat motivasi belajar subjek penelitian paling banyak berada pada kategori tinggi $(50,00 \%)$ yang berarti ada pengaruh dari kondisi-kondisi ekstrinsik dan intrinsik dalam diri siswa yang mendorong siswa dalam belajar.

3. Terdapat hubugan positif antara persepsi siswa tentang sense of humor guru dengan motivasi belajar siswa kelas VII SMPN 3 Batusangkar dengan koefisien korelasi $\quad \mathrm{rxy}=0,586$, dengan $\mathrm{p}=0,000 \quad(\mathrm{p}<0,01)$ hal ini dilihat dari kategori skor persepsi siswa tentang sense of humor guru dan motivasi belajar yang sama-sama 
berada pada rentang ketegori tinggi.

\section{REFERENSI}

Adi, Rukminto, Isbandi. 1994. Psikologi Pekerjaan Sosial dan Ilmu Kesejahteraan Sosial. Dasar-dasar Pemikiran. Jakarta: PT Raja Grafindo Persada

A Muri Yusuf. 1997. Metodologi Penelitian. Padang: UNP Press

Atkinson, R. L, Atkinson, R.C. 2005. Pengantar Psikologi. Jilid I. (Edisi Kedelapan). Jakarta: Erlangga.

Berk A. Ronald. 2006. Laughterpiece Theatre: Humor as a Systematic Teaching Tool. Essays on Teaching Excellence Toward the best in the Academy. Johns Hopkins University Vol.17, No.2.

Hawkins, Drew A. 2008. Comparing The Use Of Humor to Other Coping Mechanism In Relation to Maslach's Theory of Burnout. University of Florida.

Hughes, Larry. W. 2008. A. Correlation Study of the Relationship Between Sense of Humor and Positive Pyschological Capacities in Adult, Continuing, and community Education, University of Missouri-st. Louis, MO, October 4-6,2006

Martin, Rood A. 2010. Sense of humor. University of Western Ontario. Handbook of positive psychological assessment. Diakses tanggak 14 mei 2010 pukul 00.29 wib.
Maier, W. Whimsical Wisdom. 2008.

AMS Conference, garden grove, CA., wmaier@lexmontessoru.org.

Diakses tanggal 12 juni 2010 pukul 23.15 wib.

Muchlas machmuri. 1994. Perilaku organisasi. Yogyakarta: UGM

Nabar, Darmansyah. 2009. Pengaruh Sisipan Humor Terhadap Kecerdasan Emosional dan Hubungannya dengan Hasil Belajar.

http://www/blogger.com. diakses tanggal 18 Juli 2010 pukul 22.05 wib

Prayitno, Elida. 1989. Motivasi dalam Belajar. FKIP IKIP Padang.

Purwanto, M. Ngalim. 2007. Psikologi Pendidikan. Bandung: PT Remaja Rosdakarya.

Santrock. J.W. 2008. Psikologi Pendidikan. Edisi Kedua. Jakarta: Kencana

Sardiman. 2003. Interaksi dan Motivasi Belajar Mengajar. Jakarta: PT Raja Grafindo Persada.

Suharsimi Arikunto. 1997. Manajemen Penelitian. Jakarta: Rineka Cipta

Thorson. J. A. 1997. Relationship of death anxiety and sense of humor. Psychological reports

Utomo.U.H.2007. Peran Teknologi Media Iklan dalam Internalisasi Nilai-nilai Pemahaman Arti dan Manfaat Humor. Seminar Nasional Teknologi. Yogyakarta 